\title{
The localisation and expression of $5 \alpha$-reductase Types I and II mRNAs in human hyperplastic prostate and in prostate primary cultures
}

\author{
F K Habib, M Ross, C W Bayne, K Grigor ${ }^{3}$, A C Buck ${ }^{4}$, P Bollina ${ }^{1}$ \\ and K Chapman ${ }^{2}$ \\ University Departments of Surgery, ${ }^{1}$ Urology and ${ }^{2}$ Medicine, Western General Hospital, ${ }^{3}$ Department of Pathology, University Medical School, \\ Edinburgh EH4 2XU, UK and ${ }^{4}$ Department of Urology, Glasgow Royal Infirmary, Glasgow G31 2ER, UK \\ (Requests for offprints should be addressed to F K Habib, University Department of Surgery (WGH), Western General Hospital, Edinburgh EH4 2XU, UK)
}

\begin{abstract}
The expression and localisation of mRNAs for $5 \alpha$ reductase Type I $(5 \alpha \mathrm{R}-\mathrm{I})$ and Type II $(5 \alpha$ R-II $)$ isoenzymes in human benign prostatic hyperplasia (BPH) were investigated by RT-PCR and by in situ hybridisation (ISH) using digoxigenin labelled riboprobes. In addition, we also examined the isoenzymes mRNA expression in primary BPH cultures of separated stroma/fibroblast and epithelial cells to determine whether primary cultures are appropriate models in which to investigate $5 \alpha \mathrm{R}$ activity and regulation. The results demonstrated conclusively the presence of mRNA encoding both isoenzymes in all specimens so far examined. Additionally, the presence of a functional $5 \alpha$ R-I and -II activity in BPH was confirmed by enzyme assays. ISH studies localised the mRNA expression to both the fibroblast/stromal component as
\end{abstract}

well as the epithelial cells of the hyperplastic tissue. In the glandular regions the expression for both isoenzymes was particularly strong in the basal layers of the epithelium whereas mRNA expression in the secretory cells was less pronounced. Expression of $5 \alpha \mathrm{R}-\mathrm{I}$ and -II mRNAs in fibroblast was on the other hand variable with high expression in some areas and little in others. These findings were supported by our primary culture experiments which demonstrated that both the fibroblast and epithelial cells maintain a capacity to express both isoenzymes in vitro. In the case of the fibroblast, the capacity to express the isoenzymes was maintained following the sequential passaging of the cells up to passage 6 , after which the cells no longer expressed either isoenzyme.

Journal of Endocrinology (1998) 156, 509-517

\section{Introduction}

The development of benign prostatic hyperplasia (BPH) is a process dependent on a number of factors including testicular androgen and aging. The active androgen regulating the growth and function of the prostate is $5 \alpha$ dihydrotestosterone ( $5 \alpha \mathrm{DHT}$ ) which, in vivo, is formed by the irreversible reduction of testosterone by the enzyme $5 \alpha$ reductase $(5 \alpha \mathrm{R})$ (cholesterone $5 \alpha$-reductase, 3 -oxo- $5 \alpha$ steroid:NADP ${ }^{+}$4-ene-oxidoreductase, EC1·3·1·22). 5 $\alpha$ R activity can therefore play an important role in the development of the prostate gland in health and disease (Anderson \& Liao 1968, Bruchovsky \& Wilson 1968) and represents a key therapeutic target.

In recent years, much attention has focussed on the important issue of whether there is more than one form of $5 \alpha \mathrm{R}$ in the male reproductive system. Kinetic analysis of the metabolism of testosterone in the prostate highlighted the presence of two isoforms of the enzyme in $\mathrm{BPH}$ (Rennie et al. 1983, Hudson \& Wherrett 1990) whereas other studies involving the solubility of the enzymes
(Moore \& Wilson 1974, Scheer \& Robaire 1983, Houston et al. 1985a, Sargent \& Habib 1991) demonstrated only one component. These reports were further complicated by the fact that there was no consensus on the intracellular distribution of the enzymes, with earlier investigations indicating that the enzymes were found in the microsomes, in the nuclear membrane or in both (Moore \& Wilson 1972, Bruchovsky et al. 1981, Hudson 1981, Houston et al. 1985b, Enderle-Schmitt et al. 1986).

However, these conflicting messages have now been resolved, due mainly to the recent successes in cloning the genes responsible for the two steroid $5 \alpha \mathrm{R}$ isoenzymes, designated Types I and II, which have been characterised in a variety of tissues from man and rat (Andersson et al. 1989, 1991, Andersson \& Russell 1990, Jenkins et al. 1992). The Type I enzyme ( $5 \alpha \mathrm{R}-\mathrm{I})$, which in man maps to chromosome 5 , is expressed in large amounts in skin and liver. The Type II enzyme ( $5 \alpha$ R-II), which shows $50 \%$ nucleotide identity with Type I, is located on chromosome 2 and is expressed mainly in male reproductive tissues: $5 \alpha$ R-II mRNA and protein have been demonstrated in 
normal adult prostate, as well as in BPH. Mutations in $5 \alpha$ R-II result in male pseudohermaphroditism and lack of prostate formation (Andersson et al. 1991) suggesting a central role for the $5 \alpha \mathrm{R}-\mathrm{II}$ isoenzyme in the normal development of the prostate. However the possible presence of $5 \alpha$ R-I in human prostate remains controversial. Whilst some studies reported the absence of $5 \alpha$ R-I mRNA and protein in human prostate (Thigpen et al. 1993, Silver et al. 1994), other investigations demonstrated $5 \alpha$ R-I expressed in primary prostate tissue by Northern analysis (Bonnet et al. 1993) and in cultures of epithelial cells (Hirsch et al. 1993). However neither study addressed the important issue of whether the two isoenzymes were expressed in intact BPH tissue or established their cellular distribution within the gland. To resolve this matter we have investigated the presence of mRNAs encoding the two isoenzymes in freshly obtained $\mathrm{BPH}$ specimens, measured the functional activities of the enzymes by following the conversion of $\left[{ }^{3} \mathrm{H}\right]$ testosterone to $\left[{ }^{3} \mathrm{H}\right] \mathrm{DHT}$ at basic and acidic $\mathrm{pH}$ and investigated their cellular distribution within the hyperplastic prostate. In addition, we have explored the mRNA expression of $5 \alpha$ R-I and -II in primary cultures of prostate stromal/fibroblast and epithelial cells at different stages of passaging to demonstrate whether normal cellular expression/distribution of the isoenzymes was retained in culture.

\section{Materials and Methods}

\section{Source of prostate tissue}

Hyperplastic prostate specimens were obtained from 15 patients undergoing transurethral resection to relieve bladder obstruction. These specimens were either snap frozen in liquid nitrogen immediately following removal for mRNA analysis or placed in ice cold R.P.M.I 1640 medium (Gibco, Paisley, Strathclyde, UK) containing 5\% foetal calf serum (FCS, Gibco) and transported to the laboratory for primary culture experiments. Random selected chippings from each specimen were sent to pathology for histological examination. In addition, archival paraffin-embedded BPH material was obtained from the Department of Pathology for use in the in situ hybridisation studies. Serial $5 \mu \mathrm{m}$ sections were cut and alternate sections were stained by haematoxylin and eosin ( $\mathrm{H}$ and $\mathrm{E})$ to confirm morphology.

\section{Primary cultures of prostate fibroblast and epithelial cells}

Human prostatic fibroblast and epithelial cells were cultured from prostate chips as previously described (Habib 1992, Tsugaya et al. 1996). Verification of the purity of the fibroblast and epithelial cells was established by immunohistochemical staining employing a variety of primary monoclonal antibodies and by phase contrast microscopy as detailed in our earlier reports (Habib 1992, Tsugaya et al. 1996).

\section{Measurement of $5 a \mathrm{R}$ activity}

Primary culture of prostate fibroblast and epithelial cells Fibroblast $\left(4 \cdot 0 \times 10^{4}\right.$ cells/well $)$ and epithelial cells $\left(4 \cdot 0 \times 10^{4}\right.$ cells/well $)$ were plated in $24-$ well plates and allowed to grow for 2 days until they reached approximately $80 \%$ confluence. At this stage, culture medium was replaced with fresh medium containing radiolabelled testosterone substrate $\left(1,2,6,7-\left[{ }^{3} \mathrm{H}\right]\right.$ testosterone; specific activity $91 \mathrm{Ci} / \mathrm{mmol}$; Amersham International, Amersham, Bucks, UK) and cells were incubated at $37^{\circ} \mathrm{C}$ for periods of up to 5 days. In addition, three wells containing the medium and substrate but no cells were also included, to account for breakdown of $\left[{ }^{3} \mathrm{H}\right]$ testosterone. At the end of the incubation, the medium was collected and transferred to extraction tubes, followed by the addition of approximately 1000 c.p.m. $\left[{ }^{14} \mathrm{C}\right]$ labelled steroids for each of the androgens to be assayed to calculate losses. Subsequent steps, including extraction and separation of steroids, development of thin layer chromatography plates and the recovery of steroids, have all been described previously (Houston et al. 1985a, Tsugaya et al. 1996).

Tissue homogenates Tissue homogenates were prepared by pulverising frozen tissue $(2-5 \mathrm{~g})$ and homogenising in approximately five volumes of $40 \mathrm{mM}$ sodium phosphate buffer containing $0 \cdot 32 \mathrm{M}$ sucrose and $1 \mathrm{mM}$ dithiothreitol (DTT) at either $\mathrm{pH} 7 \cdot 5$ for $5 \alpha \mathrm{R}-\mathrm{I}$ or $\mathrm{pH} 5.0$ for $5 \alpha$ R-II. The $5 \alpha$-reductase assays were set up in tubes containing an NADPH generating system as described by Tsugaya et al. (1996) and the reactions proceeded following the addition of $200 \mu$ l homogenate along with $\left[{ }^{3} \mathrm{H}\right]$ testosterone solution $(20 \mathrm{nM} ; 1 \mu \mathrm{Ci})$. The tubes were incubated in a shaking water bath at $37^{\circ} \mathrm{C}$ for $30 \mathrm{~min}$ and the reactions were stopped by the addition of two volumes of diethylether containing 500 c.p.m. $\left[{ }^{14} \mathrm{C}\right] \mathrm{DHT}$ and $25 \mu \mathrm{g}$ each of unlabelled steroids. Details of the remaining procedures for the extraction of steroids, their separation on ILTC plates and the correction for procedure losses are described in Houston et al. (1985).

Protein levels were determined using a Bio-Rad kit (Bio-Rad Laboratories Ltd, Hemel Hampstead, Herts, UK) and enzyme activity was expressed as a function of the protein concentration. The activities of $5 \alpha \mathrm{R}-\mathrm{I}$ $(\mathrm{pH} 7 \cdot 5)$ and $5 \alpha \mathrm{R}-\mathrm{II}(\mathrm{pH} 5 \cdot 0)$ were also measured in the presence of the $5 \alpha$ R-II inhibitor (Moore et al. 1995, Habib et al. 1997), Finasteride, at a concentration of $270 \mathrm{nM}$.

\section{Preparation of RNA}

Total cellular RNA was extracted using the acidguanidium-phenol-chloroform (AGPC) method of 
Chomczynski \& Sacchi (1987). Poly(A) ${ }^{+}$RNA was prepared using the poly A tract mRNA isolation system (Promega, Southampton, Hants, UK) employing paramagnetic beads.

\section{Reverse transcription-polymerase chain reaction ( $R T-P C R)$}

One microgram total RNA or $0 \cdot 1 \mu \mathrm{g}$ poly $(\mathrm{A})^{+}$RNA was reverse transcribed in $10 \times$ reaction buffer (Promega) containing $2 \mu \mathrm{l} 10 \mathrm{mM}$ dNTP mix (Pharmacia, Milton Keynes, Bucks, UK), 20 U RNAsin (Promega), 500 ng oligo $(\mathrm{dT})_{15}$ primer (Promega), $5 \mathrm{mM} \mathrm{MgCl}_{2}$ and $15 \mathrm{U}$ avian myeloblastosis virus reverse transcriptase (Promega). Reactions were incubated at $42{ }^{\circ} \mathrm{C}$ for $60 \mathrm{~min}$ then $20 \mu \mathrm{l}$ reaction mix were used for PCR amplification. PCRs were performed in a volume of $100 \mu$ l containing $0 \cdot 2 \mathrm{mM}$ dNTPs (Promega), $40 \mathrm{mM} \mathrm{KCl}, 8 \mathrm{mM}$ Tris $\mathrm{HCl} \mathrm{pH}$ 9, $0.08 \%$ Triton X-100, $2 \mathrm{mM} \mathrm{MgCl}_{2}, 1.5 \mathrm{U}$ Taq DNA polymerase (Promega) and $75 \mathrm{pmol} /$ primer. Human $5 \alpha$ R-I and -II cDNAs were amplified using two sets of intron-spanning primers. Primers for the $5 \alpha$ R-I were: $5^{\prime}$ TGC TGA TGA CTG GGT AAC AG $3^{\prime}$ and $5^{\prime}$ GTT GGC TGC AGT TAC GTA TTC 3', amplifying nucleotides 453-624 (Andersson et al. 1989). Primers for $5 \alpha$ R-II were: $5^{\prime}$ CCT TGT ACG TCG CGA AGC $3^{\prime}$ and 5' CCA CCC ATC AGG GTA TTC AG 3', amplifying nucleotides 98-447 (Andersson et al. 1991).

To verify the integrity of the RNA, control RT-PCRs were performed using primers designed to amplify human cDNA encoding the housekeeping protein hypoxanthineguanine-phosphoribosyl transferase (HGPRT): $5^{\prime}$ CTT GCT CGA GAT GTG ATG AAG $3^{\prime}$ and $5^{\prime}$ GTC TGC ATT GTT TTG CCA GTG 3', which produce a PCR fragment of $310 \mathrm{bp}$. For each set of primers, PCR conditions were as follows: $95{ }^{\circ} \mathrm{C}$ for $1.5 \mathrm{~min}, 52{ }^{\circ} \mathrm{C}$ for $1 \mathrm{~min}$ and $72{ }^{\circ} \mathrm{C}$ for 5 min for 35 cycles using a Hybaid thermal reactor (Teddington, UK). Genomic DNA contamination was analysed by amplifying $1 \mu \mathrm{g}$ RNA without RT. PCR products were size fractionated and visualised by electrophoresis on $2 \%(\mathrm{w} / \mathrm{v})$ agarose gels containing $2 \mu \mathrm{g} / \mathrm{ml}$ ethidium bromide (Sigma, Poole, Dorset, UK). No DNA and no RT controls were included in each set of PCRs.

For analysis of $5 \alpha$ R-II mRNA, total RNA was used. However the presence of a $5 \alpha$ R-I pseudogene with 95\% nucleotide identity to the functional gene (Jenkins et al. 1991) prevented the use of total RNA in RT-PCRs to analyse the Type I isoenzyme mRNA because of residual amounts of genomic DNA in total RNA preparations. Therefore all RT-PCR experiments on the $5 \alpha$ R-I isoenzyme were carried out on mRNA purified from total RNA in which traces of the $5 \alpha$ R-I pseudogene had been totally eradicated (Fig. 1). When sufficient poly(A) ${ }^{+}$RNA was available, parallel studies on $5 \alpha$ R-II were also carried out and these yielded results identical to those of the RT-PCR experiments in which total RNA was used.

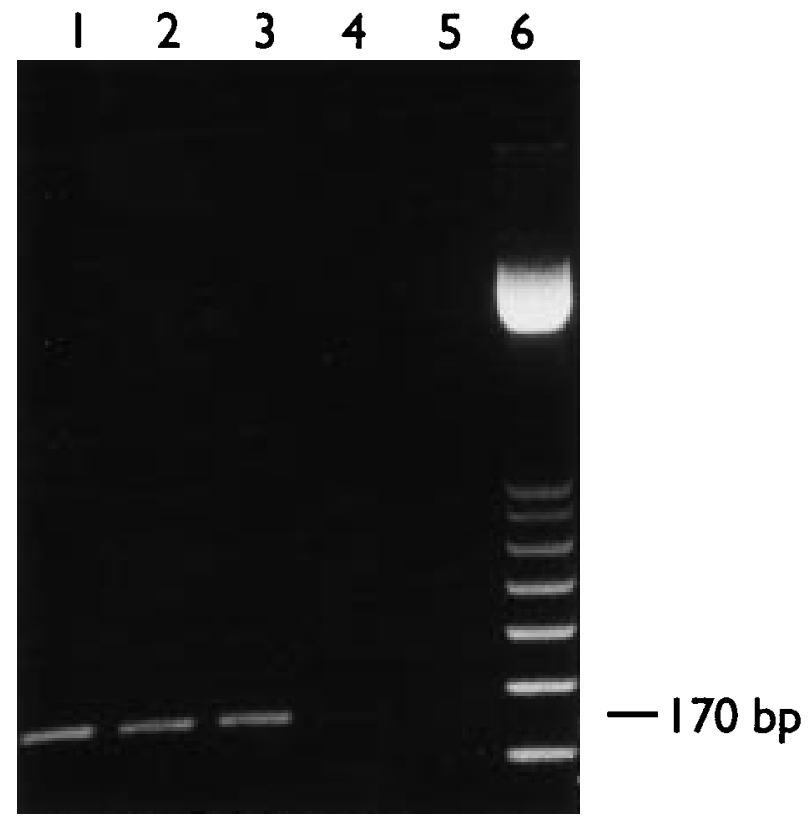

Figure 1 Elimination of the expression of $5 \alpha$ R-I pseudogene from RNA preparations derived from $\mathrm{BPH}$ tissue following RT-PCR. One microgram total RNA or $0 \cdot 1 \mu$ g poly $(\mathrm{A})^{+} \mathrm{RNA}$ was reverse transcribed and the CDNA sequences for $5 \alpha$ R-I were amplified by PCR ( 35 cycles) employing primers for $5 \alpha$ RI and Taq DNA polymerase. The PCR products and $100 \mathrm{bp}$ markers were size fractionated on $2 \%$ agarose gel, stained with ethidium bromide and visualised under UV light. Lane 1: total RNA; Lane 2: total RNA (no RT); Lane 3: poly $(\mathrm{A})^{+} \mathrm{RNA}$; Lane 4: poly $(\mathrm{A})^{+} \mathrm{RNA}$ (no RT); Lane 5: no DNA control; Lane 6: 100 bp ladder.

\section{In situ hybridisation}

Paraffin wax embedded BPH blocks were cut into $5 \mu \mathrm{m}$ thick sections and mounted on aminopropyltriethoxy silane (TESPA)-coated glass slides. Prehybridisation was carried out by baking the section for $15 \mathrm{~min}$ at $60{ }^{\circ} \mathrm{C}$ followed by dewaxing in xylene, refixing and permealisation by covering slides with $100 \mu \mathrm{l} 50 \mathrm{mM}$ Tris- $\mathrm{HCl}$ $\mathrm{pH} 7 \cdot 6$ containing $20 \mu \mathrm{g}$ Proteinase $\mathrm{K}$ (Sigma) and $5 \mathrm{mM}$ EDTA for $7.5 \mathrm{~min}$ at room temperature. Hybridisation to digoxigenin (DIG-UTP) labelled RNA probes $(1.6 \mu \mathrm{g} / 80 \mu \mathrm{l})$ was carried out in a hybridisation mixture containing $40 \mu \mathrm{l}$ formamide, $9.6 \mu \mathrm{l} 5 \mathrm{M} \mathrm{NaCl}, 1.6 \mu \mathrm{l}$ $50 \times$ Denhardt's solution, $0 \cdot 8 \mu \mathrm{l} 1 \mathrm{M}$ Tris $-\mathrm{HCl} \mathrm{pH} 7 \cdot 4$, $0.4 \mu \mathrm{l} 200 \mathrm{mM}$ EDTA, $0.8 \mu \mathrm{l} 1 \mathrm{M}$ DTT, $1.6 \mu \mathrm{l}$ tRNA $(10 \mu \mathrm{g} / \mu \mathrm{l})$ and $16 \mu \mathrm{l} 50 \%$ dextran sulphate and proceeded overnight at $50{ }^{\circ} \mathrm{C}$ in a moist chamber under unsealed silane-treated coverslips. Post hybridisation washes (30 min each) included $2 \times \mathrm{SSC}(300 \mathrm{mM}$ sodium chloride and $30 \mathrm{mM}$ sodium citrate) at $37^{\circ} \mathrm{C}$ followed by a single wash in $2 \times \mathrm{SSC}$ at room temperature before RNase treatment $\left(30 \mathrm{~min}\right.$ at $37^{\circ} \mathrm{C}$ in $2 \times$ SSC containing $10 \mu \mathrm{g} / \mathrm{ml}$ RNase-A) then washed in $2 \times$ SSC for $20 \mathrm{~min}, 2 \times \mathrm{SSC}$ containing $50 \%$ formamide at $65^{\circ} \mathrm{C}$ for $20 \mathrm{~min}, 2 \times \mathrm{SSC}$ at $65^{\circ} \mathrm{C}$ for $20 \mathrm{~min}, 0 \cdot 2 \times \mathrm{SSC}$ at room 

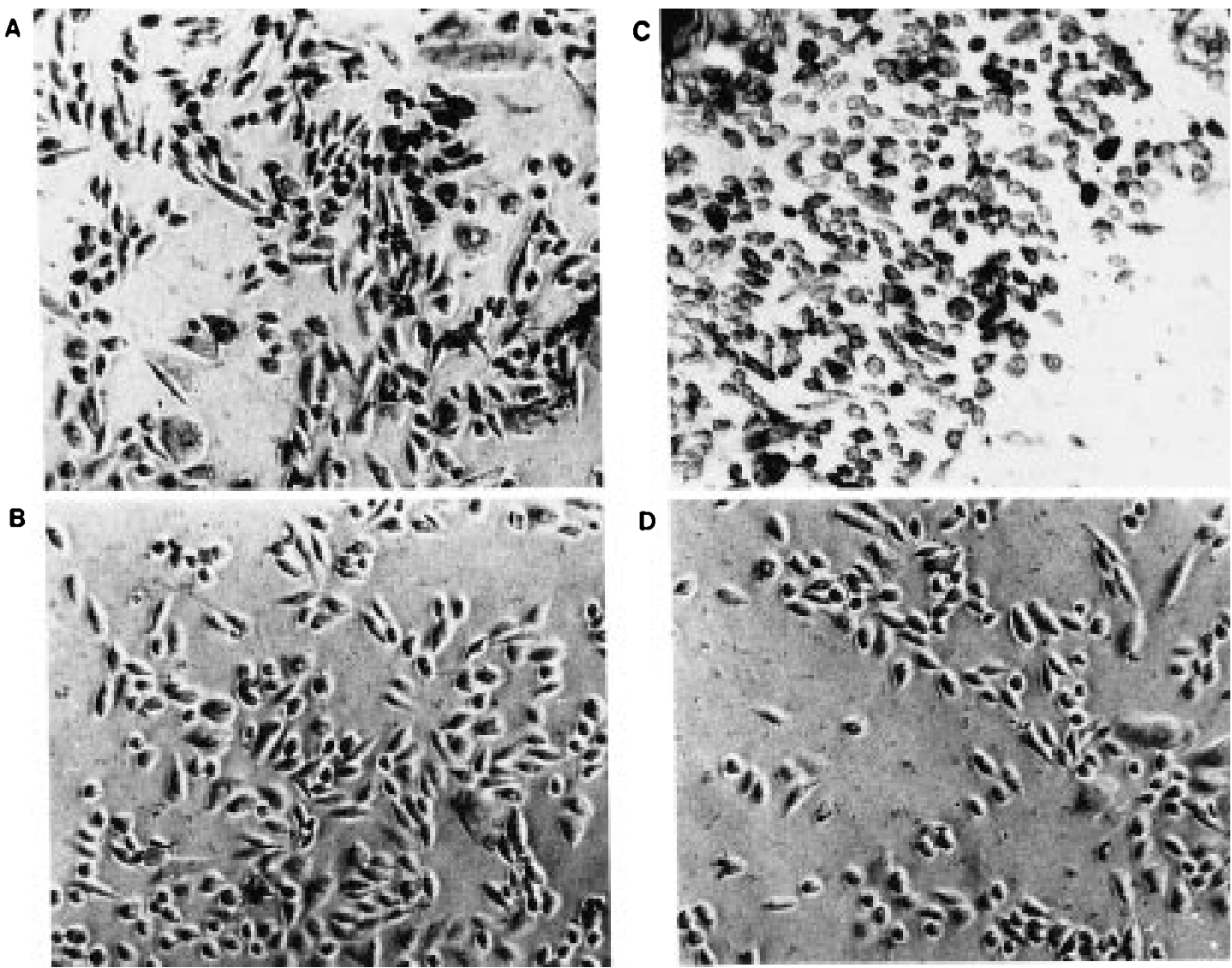

Figure 2 Specificity of the $5 \alpha$ R-I and -II mRNA antisense probes. CHO cells transfected with either the $5 \alpha$ R-I (A and B) or the $5 \alpha$ R-II (C and D) gene were hybridised with DIG-UTP labelled mRNA antisense probes either to $5 \alpha$ R Type I (A and B) or to Type II (C and D) visualised by immersion in the DIG-alkaline phosphatase conjugated antibody. Positive labelling for $5 \alpha$ R-I is seen only in (A) whereas positive labelling for $5 \alpha$ R-II is observed only in (C). (Magnification $\times 20$ ).

temperature for $10 \mathrm{~min}$ and finally in $0 \cdot 1 \times \mathrm{SSC}$ at $42{ }^{\circ} \mathrm{C}$ for $20 \mathrm{~min}$. The hybridised riboprobes were subsequently visualised by immersion in the DIG-alkaline phosphatase conjugated antibody (Boehringer Mannheim, Lewes, Sussex, UK) at a dilution of 1:2500 for $30 \mathrm{~min}$ at room temperature after which the sections were washed in $0 \cdot 1 \mathrm{M}$ Tris $\mathrm{pH} 9.5$ containing $0.1 \mathrm{M} \mathrm{NaCl}$ and $0.05 \mathrm{M}$ $\mathrm{MgCl}_{2}$ for $30 \mathrm{~min}$ at room temperature and developed by immersion overnight in a Boehringer Mannheim developing reagent.

DIG-UTP labelled riboprobes were prepared as follows using the DIG-RNA labelling kit from Boehringer Mannheim. DIG-labelled RNA complementary to $5 \alpha$ R-I mRNA (sense and antisense probes) was synthesised from a $780 \mathrm{bp}$ fragment cDNA probe of human $5 \alpha$ R-I cDNA (Andersson et al. 1989), subcloned into pBSII SK and linearised either with KpnI using T7 RNA polymerases for the antisense probe or with NoTI using T3 RNA polymerase for the sense probe, as detailed in the manufacturer's protocol. The DIG-labelled riboprobes for the $5 \alpha \mathrm{R}-\mathrm{II}$ isoenzyme were synthesised in a similar fashion except that a $365 \mathrm{bp}$ cDNA probe ( $5 \alpha \mathrm{R}$-II; Andersson et al. 1991) complementary to the $5 \alpha$ R-II mRNA was used. The specificity of the $5 \alpha$ R-I and -II antisense probes was checked by in situ hybridisation of $\mathrm{CHO}$ cells which had been transfected with either the $5 \alpha$ R-I or -II gene. The results showed no cross-reactivity between the probes (Fig. 2A-D). For negative control, hybridisation with sense-strand riboprobes was also carried out on $\mathrm{BPH}$ sections.

\section{Results}

\section{$5 a \mathrm{R}-I$ and $5 a \mathrm{R}$-II gene expression in BPH specimens}

The mRNA expression for $5 \alpha$ R-I and -II was investigated in nine BPH specimens. Figure 3 demonstrates the PCR products corresponding to the expected sizes for $5 \alpha$ $\mathrm{R}-\mathrm{I}(170 \mathrm{bp})$ and $5 \alpha \mathrm{R}-\mathrm{II}(350 \mathrm{bp})$ mRNA isolated from $\mathrm{BPH}$ tissue. Identity of the two PCR products was confirmed by restriction enzyme digest using HinfI for $5 \alpha$ R-I and Ncil for $5 \alpha$ R-II. HinfI is predicted to cleave the 


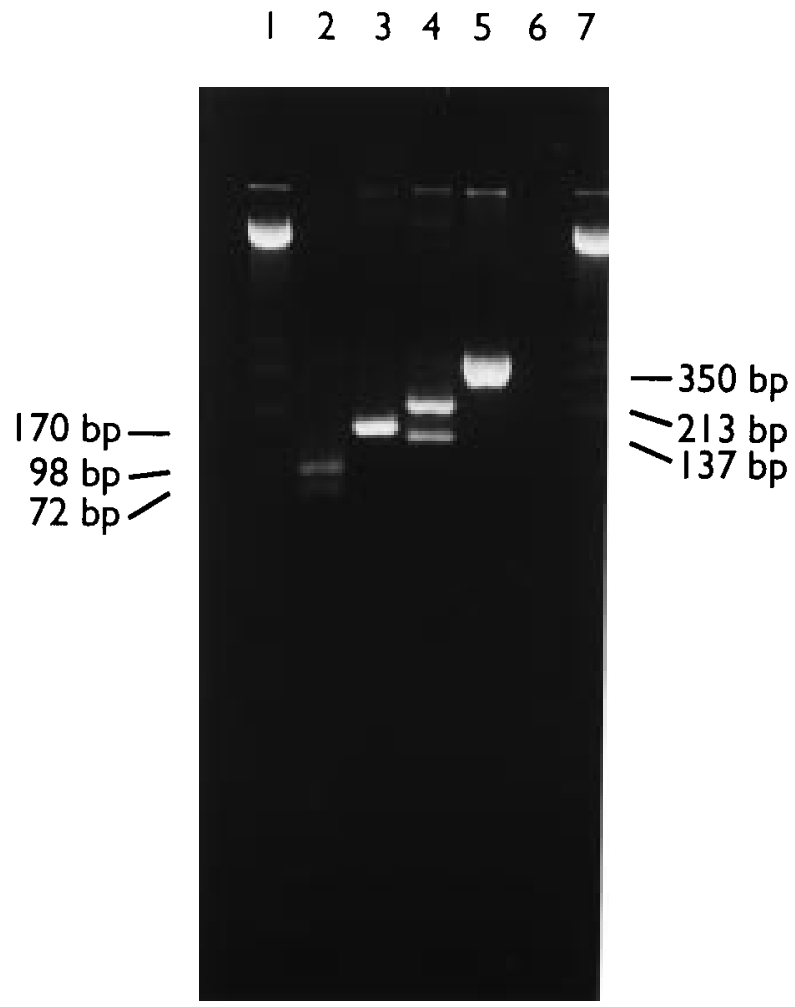

Figure 3 The expression of $5 \alpha$ R-I and -II mRNA by RT-PCR in $\mathrm{BPH}$ tissue. One microgram total RNA $(5 \alpha \mathrm{R}-\mathrm{II})$ or $0 \cdot 1 \mu \mathrm{g} \operatorname{poly}(\mathrm{A})^{+}$ RNA $(5 \alpha \mathrm{R}-\mathrm{I})$ isolated from BPH tissues was reverse transcribed and the cDNA sequences for $5 \alpha$ R-I (170 bp) and $5 \alpha$ R-II (350 bp) were amplified by PCR (35 cycles) employing primers for $5 \alpha$ R-I (lane 3 ) and $5 \alpha$ R-II (lane 5). The products were specifically cleaved with Hinfl ( $5 \alpha$ R-I) to yield fragment sizes 98 and 72 bp (lane 2) and Ncil (5 $\alpha$ R-II) to yield fragment sizes 213 and 137 bp (lane 4). No DNA control is in lane 6 . The PCR products and $100 \mathrm{bp}$ markers (lanes 1 and 7) were size fractionated on a $2 \%$ agarose gel stained with ethidium bromide and visualised under UV light. The size of the bands are indicated on the left and right margins.

170 bp $5 \alpha$ R-I product once, producing restriction fragments of $72 \mathrm{bp}$ and $98 \mathrm{bp}$, whilst Ncil should cleave the 350 bp $5 \alpha$ R-II product, producing two fragments of 137 and 213 bp (Fig. 3). Analysis carried out on RNA isolated from nine patients is detailed in Table 1 . In each case, a single PCR product was seen for each of $5 \alpha$ R-I and -II and no competition between Type I and II fragments under the conditions used (Fig. 3).

\section{Localisation of the $5 a$ R-I and $5 a$ R-II $m R N A$ in BPH}

In situ hybridisation was carried out on wax-embedded BPH sections obtained from four different patients. DIG-UTP labelled antisense riboprobes complementary to $5 \alpha$ R-I and -II RNAs demonstrated strong mRNA expression for both the $5 \alpha$ R-I and -II in the glandular areas of all $\mathrm{BPH}$ specimens, but weaker staining in the stromal/fibroblast component (Figs 4 and 5). We also noted that ( $5 \alpha$ R-I and -II) labelling in the glandular areas was stronger and more pronounced in the basal cells whereas the secretory cells demonstrated a much lower expression. Furthermore, labelling of epithelial cells was uniform throughout the four specimens examined but there was considerable variability in the labelling patterns of the stromal/fibroblast component. Hybridisation experiments employing the sense probes for both the $5 \alpha$ R-I and -II enzymes yielded no specific signal (Figs 4 and 5).

$m R N A$ expression of $5 a R$ isoenzymes in primary cultures of prostate fibroblast and epithelial cells

In order to determine whether primary cultures are appropriate models in which to investigate $5 \alpha \mathrm{R}$ activity and regulation, we have used a qualitative RT-PCR to examine the mRNA expression of $5 \alpha$ R-I and -II in epithelial cells (Fig. 6) and fibroblasts (Fig. 7) cultured separately from six freshly obtained $\mathrm{BPH}$ specimens. As summarised in Table 1, both fibroblast and epithelial cells contained mRNAs encoding isoenzymes as demonstrated by PCR products of $170 \mathrm{bp}$ for $5 \alpha$ R-I (Figs 6 and 7) and $350 \mathrm{bp}$ for $5 \alpha$ R-II (Figs 6 and 7). Restriction digestion of PCR products with Hinfl (5 $\alpha$ R-I) and NCiI ( $5 \alpha$ R-II) confirmed the identity of the PCR products thus demonstrating that both the fibroblast and epithelial cells expressed mRNA for both isoenzymes. Expression of mRNA encoding both isoenzymes persisted over several passages of the fibroblast cells (Table 1; Fig. 7). RT-PCR demonstrated the presence of $5 \alpha$ R-I and -II mRNA in cells up to passage 6; at later passages, no $5 \alpha$ R-I or -II

Table 1 The expression of mRNA transcripts for both $5 \alpha$ R-I and $-\mathrm{II}$ in BPH and in primary cultures of stromal/fibroblast and epithelial cells

\begin{tabular}{|c|c|c|c|c|c|c|}
\hline & & & Strom & fibro & ast $c$ & $(6)$ \\
\hline & BPH $(9)^{*}$ & Epithelial cells $(6)$ & ${ }^{* *} \mathrm{p}-2$ & $\mathrm{p}-4$ & p-6 & $\mathrm{p}-8$ \\
\hline $5 \alpha$ red & & & & & & \\
\hline RT-PCR & & & & & & \\
\hline Type I & + & + & + & + & + & - \\
\hline Type II & + & + & + & + & + & - \\
\hline
\end{tabular}



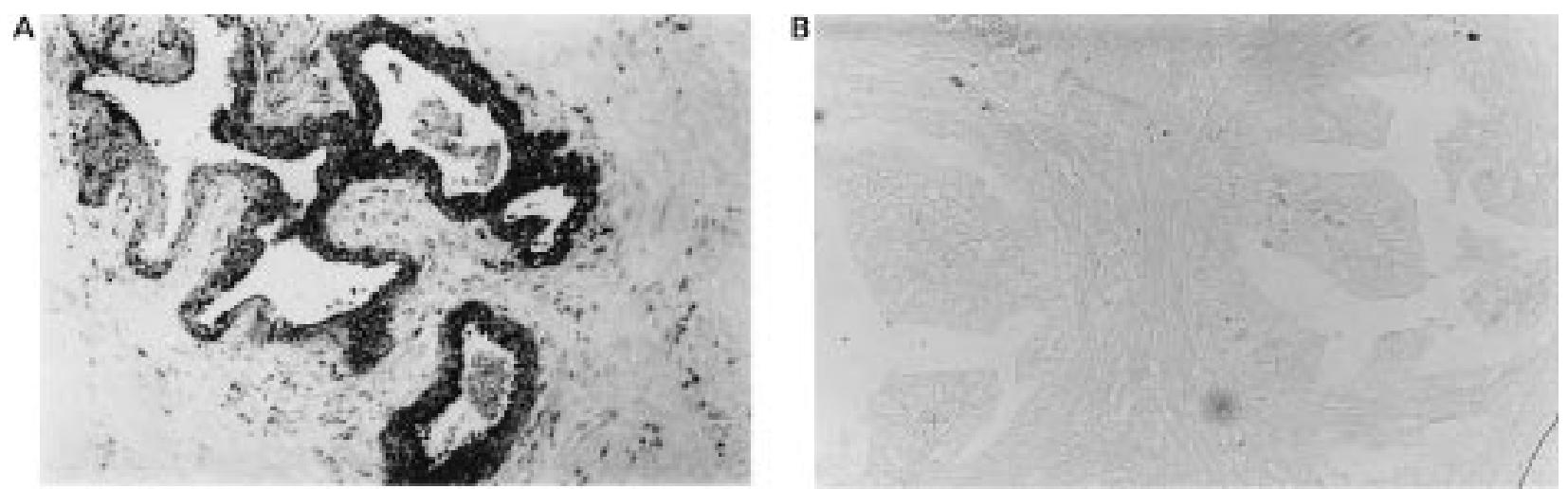

Figure 4 Localisation of $5 \alpha$ R-I in BPH tissue by in situ mRNA hybridisation. Hybridisation was carried out with DIG-UTP labelled $5 \alpha$ R-I mRNA anti-sense (A) and sense (B) strand probes and visualised by immersion in the DIG-alkaline phosphatase conjugated antibody. A, positive labelling for $5 \alpha \mathrm{R}-\mathrm{I}$ is seen mainly in the basal epithelial cells, but some staining is also observed in the secretory cells and in the stromal/fibroblast cells. B, no labelling with sense probe (negative control). Magnification: $\times 25$.
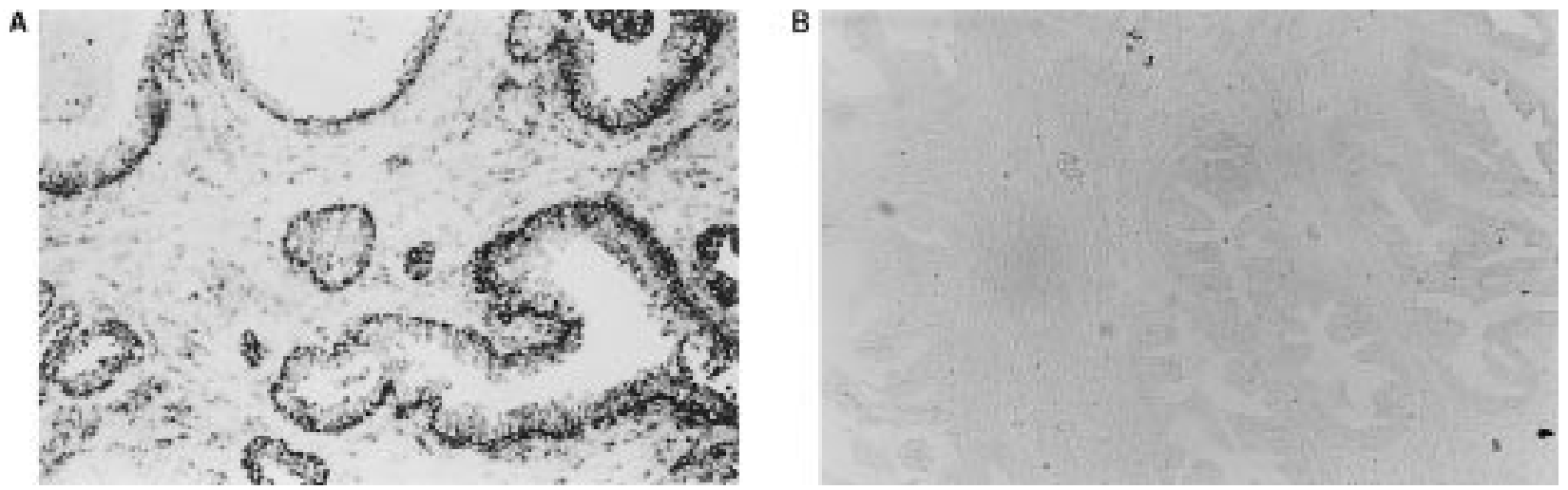

Figure 5 Localisation of $5 \alpha$ R-II in BPH tissue by in situ mRNA hybridisation. Hybridisation was carried out with DIG-UTP labelled $5 \alpha$ R-II mRNA anti-sense (A) and sense (B) strand probes and visualised by immersion in the DIG-alkaline phosphatase conjugated antibody. A, positive labelling for $5 \alpha \mathrm{R}$-II is seen mainly in the basal epithelial cells, but some staining also in the secretory cells and in the stroma/fibroblast cells. B, no labelling with sense probes (negative control). Magnification: $\times 25$.

mRNA was detectable by RT-PCR (Table 1; Fig. 7). Because of the difficulties in passaging epithelial cells, we were unable to investigate the impact of serial passaging of these cells on the mRNA expression of the isoenzymes.

$5 a R$ activity in primary culture of fibroblast and epithelial cells and in human BPH homogenates

Primary cultures were tested for $5 \alpha \mathrm{R}$ activity by measuring the metabolites formed following incubation of the cells with radiolabelled testosterone. The results obtained from eight separate incubations demonstrated that the metabolism of testosterone and the formation of DHT in the epithelial cells (means \pm s.E.M.: $4 \cdot 4 \times$ $10^{-8} \pm 0 \cdot 12 \mathrm{pmol} / \mathrm{cell} / \mathrm{h}$ ) was slightly greater than the activity measured in the fibroblasts $\left(2.6 \times 10^{-8} \pm\right.$ $0.21 \mathrm{pmol} / \mathrm{cell} / \mathrm{h})$. However the live cell assay does not differentiate between the activities of the Type I and II isoenzymes and in all probability the values obtained represent a combination of the two activities. With repeated passaging of the fibroblast cells, $5 \alpha \mathrm{R}$ activity gradually diminished and became undectable by passage 3 (data not shown).

We also examined the metabolism of $\left[{ }^{3} \mathrm{H}\right]$ testosterone to $\left[{ }^{3} \mathrm{H}\right]$ DHT by homogenates from four separate BPH tissues each run in triplicate. Both $5 \alpha$ R-I and -II activities were detected but the mean \pm S.E.M. $5 \alpha$ R-II activity $(0.426 \pm 0.058 \mathrm{pmol} / \mathrm{mg}$ protein $/ \mathrm{h})$ was higher than that for $5 \alpha \mathrm{R}-\mathrm{I}(0 \cdot 128 \pm 0 \cdot 032 \mathrm{pmol} / \mathrm{mg}$ protein $/ \mathrm{h})$. Furthermore, our studies confirmed Finasteride as a potent inhibitor for $5 \alpha \mathrm{R}-\mathrm{II}$ inducing a $75 \%$ decrease in the activity of this enzyme $(0 \cdot 109 \pm 0 \cdot 018 \mathrm{pmol} / \mathrm{mg}$ protein $/ \mathrm{h})$. However the inhibitor had little effect on the activity of $5 \alpha$ R-I which was very slightly depleted $(0 \cdot 114 \pm 0 \cdot 016 \mathrm{pmol} / \mathrm{mg}$ protein/h). 


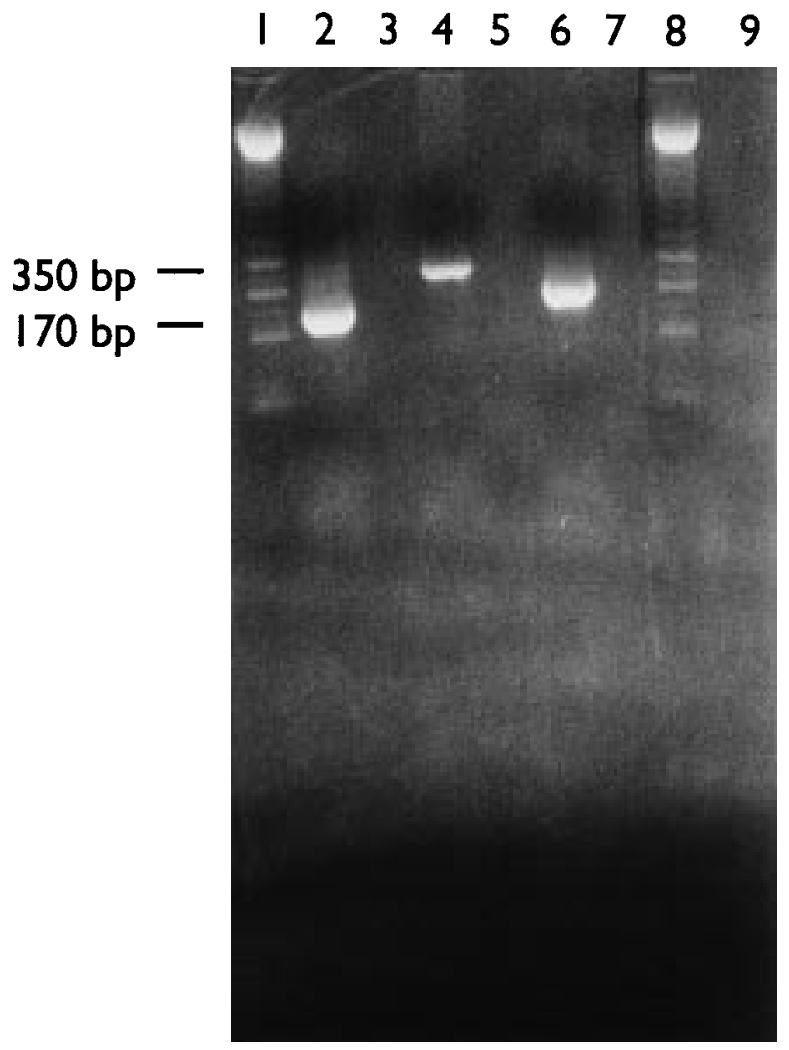

Figure 6 The RT-PCR expression of $5 \alpha$ R-I and -II mRNA in primary cultures of epithelial cells from $\mathrm{BPH}$. One microgram total RNA ( $5 \alpha$ R-II) or $0 \cdot 1 \mu \mathrm{g}$ poly $(\mathrm{A})^{+}$RNA $(5 \alpha$ R-I) isolated from primary cultures of epithelial cells from BPH tissue was used to prepare cDNA in an oligo-dT primed reverse transcription. cDNAs were subjected to 35 cycles PCR with either $5 \alpha$ R-I or -II primers and the resulting products separated on a $2 \%$ agarose gel containing ethidium bromide. The PCR products were visualised under UV light. Lane 1: 100 bp ladder; Lane 2: epithelium/5 $\alpha$ R-I; Lane 3: $5 \alpha$ R-I negative control (no RT); Lane 4: epithelium/5 $\alpha$ R-II; Lane 5: $5 \alpha$ R-II negative control (no RT); Lane 6: epithelium/ HGPRT; Lane 7: HGPRT negative control (no RT); Lane 8: 100 bp ladder; Lane 9: no DNA control.

\section{Discussion}

The results described in this report demonstrated conclusively that mRNAs encoding both $5 \alpha$ R-I and -II isoenzymes are expressed in human BPH tissue. Using RT-PCR we have shown mRNA expression for both isoenzymes in nine out of nine $\mathrm{BPH}$ tested. In situ hybridisation further demonstrated the cellular distribution of these isoenzymes in the epithelial as well as in the fibroblast components of the prostate. This was subsequently confirmed by primary cultures which demonstrated expression of mRNA encoding $5 \alpha$ R-I and -II in both fibroblast and epithelial cells. The presence of a functional $5 \alpha$ R-I and -II in BPH was also established by enzyme assay. The activity for both isoenzymes was demonstrated in the tissue, with the Type II exhibiting

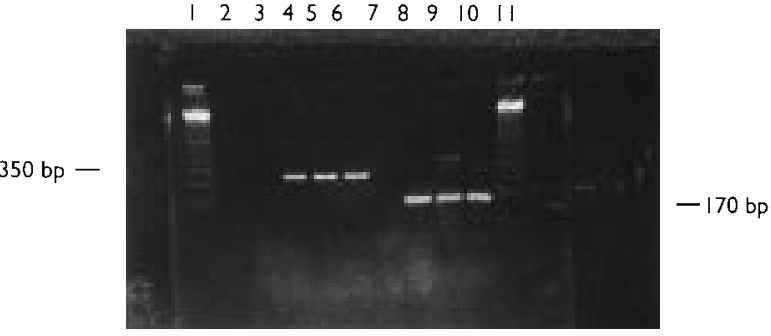

Figure 7 The RT-PCR expression of $5 \alpha$ R-I and -II mRNA in primary cultures of $\mathrm{BPH}$ fibroblast from $\mathrm{BPH}$ at different passages. One microgram total RNA ( $5 \alpha$ R-II) or $0 \cdot 1 \mu$ g poly $(A)^{+}$RNA ( $5 \alpha$ $\mathrm{R}-\mathrm{I})$ isolated from primary cultures of fibroblast cells derived from $\mathrm{BPH}$ tissue was used to prepare cDNA in an oligo-dT primed reverse transcription. cDNAs were subjected to 35 cycles PCR and the resulting products for $5 \alpha$ R-I (170 bp) and $5 \alpha$ R-II (350 bp) were electrophoresed on $2 \%$ agarose gels containing ethidium bromide and visualised under UV light. Lane 1: $100 \mathrm{bp}$ ladder; Lane 2: no DNA control for $5 \alpha \mathrm{R}-\mathrm{I}$ and -II; Lane 3: RT

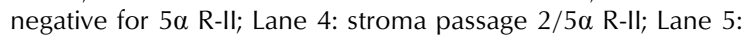
stroma passage 4/5 $\alpha$ R-II; Lane 6: stroma passage 6/5 $\alpha$ R-II; Lane 7: RT negative for $5 \alpha \mathrm{R}-\mathrm{I}$; Lane 8: stroma passage 2/5 $\alpha$ R-I; Lane 9: stroma passage 4/5 $\alpha$ R-l; Lane 10: stroma passage 6/5 $\alpha$ R-I; Lane 11: 100 bp ladder.

approximately three times as much activity as that measured for $5 \alpha$ R-I. The presence of an activity for either isoenzyme in $\mathrm{BPH}$ was also confirmed by the use of Finasteride, which selectively inhibited $5 \alpha$ R-II but was a poor inhibitor of $5 \alpha \mathrm{R}-\mathrm{I}$.

There is general consensus that $5 \alpha \mathrm{R}-\mathrm{II}$ is expressed in both the normal prostate and in BPH (Silver et al. 1994, Levine et al. 1996); however the presence of the $5 \alpha$ R-I enzyme and its encoding mRNA have been controversial. Bonnet et al. (1993) demonstrated, using Northern analysis, that $5 \alpha \mathrm{R}-\mathrm{I}$ and $-\mathrm{II}$ were expressed in human prostate and suggested that both enzymes were located predominantly in epithelial cells. However, Thigpen et al. (1993) were unable to detect either $5 \alpha$ R-I mRNA or protein using Northern and Western analysis respectively. Here we conclusively demonstrate the presence of $5 \alpha$ R-I mRNA in human BPH and show that the enzyme is functionally active in the hyperplastic gland.

Reports as to the cellular location of $5 \alpha \mathrm{R}$ are also controversial: in rat, $5 \alpha$ R-I is in basal epithelial cells and the $5 \alpha$ R-II in stroma (Berman \& Russell 1993). Silver et al. (1994) have reported that human $5 \alpha \mathrm{R}-\mathrm{II}$ in some $\mathrm{BPH}$ specimens is predominantly in the basal epithelial cells whereas in other specimens it is in both stroma and basal epithelial cells. They were, however, unable to detect $5 \alpha$ R-I in prostate by employing specific antibodies. In their studies, $5 \alpha \mathrm{R}-\mathrm{II}$ was highly expressed in stromal cells for $\mathrm{BPH}$ and $\mathrm{CaP}$. In contrast, we found a similar distribution for both mRNAs in BPH, with both isoenzymes expressed in basal epithelial and fibroblast cells. Expression in fibroblasts was variable, with high expression in some areas and little in others. These findings are 
supported by our primary culture experiments which demonstrate that both the fibroblast and epithelial cells maintain a capacity to express both isoenzymes in vitro. In the case of the fibroblast, this capacity was maintained following the sequential passaging of the cells up to passage 6 , following which the cells no longer expressed either isoenzyme. However it has not been possible for us at this stage to identify the reason for this loss of expression with repeated passaging. Our initial data on DHT supplementation of the primary cultures (work in progress) suggest that the down-regulation in $5 \alpha \mathrm{R}$ activity was not in any way linked to a depletion in DHT concentrations as previously suggested (George et al. 1991).

Because of the difficulties of passaging primary cultures of human epithelial cells, we have not been able to assess the impact of passaging of these cells on the mRNA expression of the $5 \alpha \mathrm{R}$ isoenzymes. It was however interesting to note that our observations on the expression of $5 \alpha$ R-I mRNA in epithelial cells confirm the earlier reports of $5 \alpha \mathrm{R}-\mathrm{I}$ enzyme in primary culture demonstrating that $5 \alpha \mathrm{R}$ activity in primary epithelial cultures from $\mathrm{BPH}$, inferred as the $5 \alpha \mathrm{R}$ activity in these cells, was far more susceptible to $5 \alpha$ R-I inhibitors than to $5 \alpha$ R-II inhibitors (Hirsch et al. 1993). Whilst it was not possible for us to quantify the relative activity of each isoenzyme in the primary cultures, the combined activities of $5 \alpha$ R-I and -II isoenzymes appeared to be slightly higher in the epithelial cells than in the fibroblast/stromal cultures.

The question of why the prostate has two isoforms of $5 \alpha$ $\mathrm{R}$ still remains open. The possibility that the fibroblast and epithelial cells might be expressing different isoforms has now been discounted by the results of the present study. This leaves us with another alternative and that is, whilst $5 \alpha \mathrm{R}-\mathrm{II}$ is responsible for the metabolism of testosterone to DHT, the $5 \alpha$ R-I isoenzyme might be associated with the reduction of androstenedione to androstanedione. To the best of our knowledge no one has so far investigated this alternative mechanism but this is a possibility which is worth exploring.

\section{Acknowledgements}

We are grateful to Dr D W Russell, University of Texas, Southwestern Medical Centre, Texas, for the gift of $5 \alpha$ reductase cDNAs encoding Types I and II. We would also like to thank Professor I R Lee, School of Biomedical Sciences, Curtin University, Perth, Australia for supplying us with the pre and post $5 \alpha \mathrm{R}$ transfected $\mathrm{CHO}$ cells. This research was supported by an educational grant from Merck Sharp \& Dohme and also by the Prostate Research Campaign UK.

\section{References}

Anderson KM \& Liao S 1968 Selective retention of dihydrotestosterone by prostatic nuclei. Nature 219 277-279.
Andersson SA \& Russell DW 1990 Structure and biochemical properties of cloned and expressed human and rat steroid 5 alpha reductase. Proceedings of the National Academy of Sciences of the USA 87 3640-3644.

Andersson SA, Bishop RW \& Russell DW 1989 Expression cloning and regulation of steroid 5 alpha reductase, an enzyme essential for male sexual differentiation. Journal of Biological Chemistry 264 16249-16255.

Andersson SA, Berman DM, Jenkins EP \& Russell DW 1991 Deletion of steroid 5 alpha reductase II gene on male pseudohermaphroditism. Nature 354 159-161.

Berman DM \& Russell DW 1993 Cell-type-specific expression of rat steroid 5 alpha reductase isoenzymes. Proceedings of the National Academy of Sciences of the USA 90 9359-9364.

Bonnet P, Reiter E, Bruyninx M, Sente B, Dombrowicz D, De Leval J, Closset J \& Hannen G 1993 Benign prostatic hyperplasia in normal prostate aging: differences in Type I and Type II 5 alpha reductase steroid hormone receptor messenger ribonucleic acid (mRNA) levels, but not in insulin-like growth factor mRNA levels. Journal of Clinical Endocrinology and Metabolism 77 1203-1208.

Bruchovsky N \& Wilson JD 1968 The conversion of testosterone to $5 \alpha$ androstane-17 beta-ol-3-one by rat prostate in vivo and in vitro. Journal of Biological Chemistry 243 2012-2021.

Bruchovsky N, McLaughlan MG, Rennie PS \& To MP 1981 Partial characterisation of stromal and epithelium forms of 5 alpha reductase in human prostate. Progress in Clinical Urological Research $\mathbf{7 5}$ 161-175.

Chomczynski P \& Sacchi N 1987 Single step method of RNA isolation by guanidium-thiocyanate-phenol-chloroform extraction. Analytical Biochemistry 162 156-159.

Enderle-Schmitt U, Volck-Badouin E, Schmitt J \& Aumuller G 1986 Functional characteristics of nuclear 5 alpha reductase from rat ventral prostate. Journal of Steroid Biochemistry 25 209-217.

George FW, Russell DW \& Wolfson JD 1991 Feed-forward control of prostate growth: dihydrotestosterone induces the expression of its own biosynthetic enzyme, steroid 5 alpha reductase. Proceedings of the National Academy of Sciences of the USA 88 844-847.

Habib FK 1992 Regulation of prostate growth in culture with the pollen extract, Cernitin T-60 and the impact of the drug on the EGF tissue profiles. In Benign Prostate Diseases, pp 120-128. Eds W Vahlensieck \& G Rutishauser. New York: George Thieme Verlag.

Habib FK, Ross M, Tate R \& Chisholm GD 1997 Differential effect of Finasteride on the tissue androgen concentrations in benign prostatic hyperplasia. Clinical Endocrinology 46 137-144.

Hirsch KS, Jones CD, Audia JE, Andersson S, McQuaid L, Stamm NB, Neubauer BL, Pennington P, Toomey RE \& Russell DW 1993 LY191704: a selective, non-steroidal inhibitor of human steroid 5 alpha reductase Type I. Proceedings of the National Academy of Sciences of the USA 90 5277-5281.

Houston B, Chisholm GD \& Habib FK 1985a Solubilization of human prostatic 5 alpha reductase. Journal of Steroid Biochemistry 22 461-467.

Houston B, Chisholm GD \& Habib FK $1985 b$ Evidence that human prostatic 5 alpha reductase is located exclusively in the nucleus. FEBS Letters 185 231-235.

Hudson RW 1981 Studies on the nuclear 5 alpha reductase of human hyperplastic prostate tissue. Journal of Steroid Biochemistry 14 579-584.

Hudson RW \& Wherrett D 1990 Comparisons of nuclear 5 alpha reduction of testosterone and androstenedione in human prostatic carcinoma and benign prostatic hyperplasia. Journal of Steroid Biochemistry 35 231-236.

Jenkins EP, Hsieh C-L, Miletovitch A, Normington K, Berman DM, Francke U \& Russell DW 1991 Characterization and chromosomal mapping of a human steroid 5 alpha reductase gene and pseudogene and mapping of the mouse homologue. Genomics II 1102-1112. 
Jenkins EP, Andersson SA, Imperato-McGinley J, Wilson JD \& Russell DW 1992 Genetic and pharmacological evidence for more than one human steroid 5 alpha reductase. Journal of Clinical Investigation 89 293-300.

Levine AC, Wang JP, Ren M, Eliashvili E, Russell DW \& Kirschenbaum A 1996 Immunohistochemical localization of steroid 5 alpha reductase 2 in the human male fetal reproductive tract and adult prostate. Journal of Clinical Endocrinology and Metabolism $\mathbf{8 1}$ 384-389.

Moore E, Bracken B, Bremner W, Geller J, Imperato-Mcginley J, McConnell J, Roy J, Tenover L, Vaughan D, Pappas F, Cook T, Gormley G \& Stoner E 1995 Proscar: five-year experience. European Urology 28 304-309.

Moore RJ \& Wilson JD 1972 Localisation of the reduced nicotinamide adenine dinucleotide phosphate-delta 4-3-keto steroid 5 alphaoxidoreductase in the nuclear membrane of the rat ventral prostate. Journal of Biological Chemistry 247 958-967.

Moore RJ \& Wilson JD 1974 Extraction of the reduced nicotinamide adenine dinucleotide phosphate: delta 4-3-keto steroid 5 alphaoxidoreductase of rat prostate with digitonin and potassium chloride. Biochemistry 13 450-456.

Rennie PS, Bruchovsky N, MacLaughlin MG, Batzold FH \& Dunstan-Adams EE 1983 Kinetic analysis of 5 alpha reductase isoenzymes in benign prostatic hyperplasia. Journal of Steroid Biochemistry 19 169-173.
Sargent NSE \& Habib FK 1991 Partial purification of human prostatic 5 alpha reductase (3-oxo-5 alpha-steroid: $\mathrm{NADP}^{+}$4-ene-oxidoreductase; EC1.3.1.22) in a stable and active form. Journal of Steroid Biochemistry and Molecular Biology 38 73-77.

Scheer H \& Robaire B 1983 Solubilisation and partial characterisation of rat epididymal delta 4 steroid 5 alpha reductase (cholesterone 5 alpha reductase). Biochemistry 211 65-74.

Silver RI, Wiley EL, Thigpen AE, Guileyardo JM, McConnell JD \& Russell DW 1994 Cell type specific expression of steroid 5 alpha reductase 2. Journal of Urology 152 438-442.

Thigpen AE, Silver RI, Guileyardo JM, Casey ML, McConnell JD \& Russell DW 1993 Tissue distribution and ontogeny of steroid 5 alpha reductase isoenzyme expression. Journal of Clinical Investigation 92 903-910.

Tsugaya M, Habib FK, Chisholm GD, Ross M, Tozawa K, Rayashi Y, Kohri K \& Tanaka S 1996 Testosterone metabolism in primary cultures of epithelial cells and stroma from benign prostatic hyperplasia. Urological Research 24 265-271.

Received 16 December 1996

Revised manuscript received 29 April 1997

Final version received 26 August 1997

Accepted 6 October 1997 